\title{
Różne oblicza mitochondrialnego koenzymu Q
}

\section{STRESZCZENIE}

K oenzym $Q$ jest rozpuszczalną w tłuszczach cząsteczką obecną we wszystkich błonach komórki, w tym w wewnętrznej błonie mitochondrialnej. Mitochondrialny koenzym Q (mQ) jest kluczowym nośnikiem elektronów łańcucha oddechowego oraz ważnym przeciwutleniaczem. Z drugiej strony, mQ uczestniczy w produkcji przez łańcuch oddechowy reaktywnych form tlenu (RFT), które powstają jako produkt uboczny metabolizmu tlenowego lub w warunkach stresu oksydacyjnego. Wzmożona produkcja mitochondrialnych RFT (mRFT) może prowadzić do szeregu uszkodzeń oksydacyjnych, które leżą u podstaw starzenia się komórek czy szeregu chorób. Oprócz tego, mRFT pełnią rolę cząsteczek sygnałowych. Za główne miejsca produkcji mRFT uważane są nośniki elektronów łańcucha oddechowego, przede wszystkim kompleksy białkowe związane z mQ. Badania wskazują na to, iż z wiekiem poziom koenzymu $Q$, a w szczególności jego zredukowanej formy, w organizmie spada. Zaburzenia związane z niedoborem koenzymu Q wiążą się głównie z nadmierną produkcją RFT oraz obniżeniem produkcji ATP, konsekwencją czego mogą być choroby mitochondrialne, choroby układu krążenia czy neurodegeneracyjne.

\section{WPROWADZENIE}

Mitochondria to złożone i wielofunkcyjne organelle, które powstały w wyniku wchłonięcia a-proteobakterii przez prekursora współczesnej komórki eukariotycznej [1]. Obecnie znane są liczne funkcje mitochondriów, związane z utrzymaniem energetycznej, metabolicznej i jonowej homeostazy w komórkach. Mitochondria biorą udział w metabolizmie lipidów, nukleotydów, apoptozie, sygnalizacji komórkowej, regulują gospodarkę wapniową, a także uczestniczą w procesach buforowania wapnia w organizmie [2]. Jednakże ich najważniejszą rolą jest produkcja energii w zmagazynowanej w cząsteczce adenozyno-5'trifosforanu (ATP) podczas fosforylacji oksydacyjnej, ostatniego etapu oddychania komórkowego prowadzącego do utleniania zredukowanych związków węgla pobranych z pożywieniem. Mitochondrialny system fosforylacji oksydacyjnej składa się z pięciu wielopodjednostkowych kompleksów białkowych, czterech tworzących łańcuch oddechowy (kompleksy I-IV) oraz syntazy ATP (kompleks V) (Ryc. 1). Kompleksy I i II przekazują elektrony ze zredukowanych nukleotydów, odpowiednio dinukleotydu nikotynoamidoadeninowego $(\mathrm{NADH})$ i dinukleotydu flawinoadeninowego $\left(\mathrm{FADH}_{2}\right)$ na zlokalizowany w błonie niebiałkowy nośnik elektronów, mitochondrialny koenzym Q (mQ), który dalej przekazuje elektrony na kompleks III. Ostatecznie elektrony przenoszone są przez cyt $c$ na kompleks IV. Efektem tego procesu jest pompowanie elektronów z macierzy mitochondrialnej do przestrzeni międzybłonowej przez kompleksy I, III, i IV co tworzy protonowy gradient elektrochemiczny który napę-

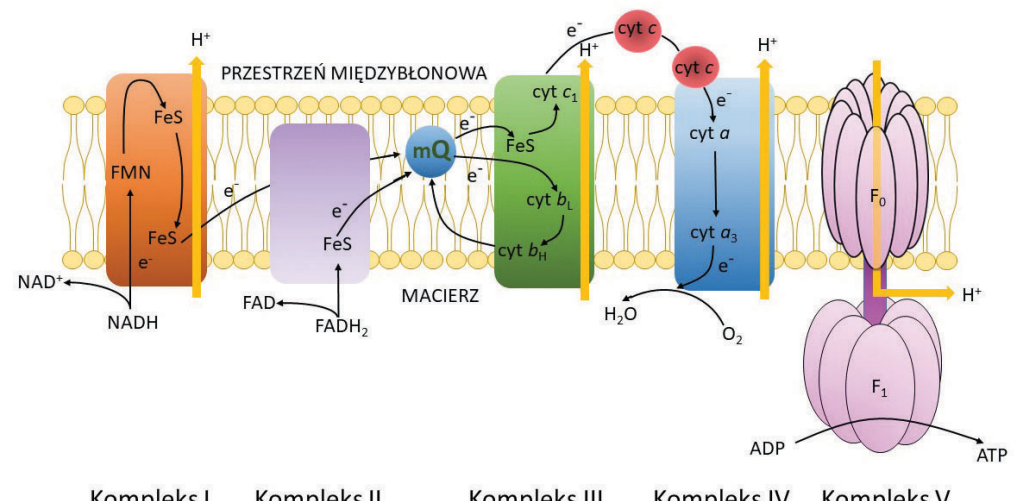

Kompleks I KompleksII Kompleks III Kompleks IV Kompleks V (syntaza ATP)

Rycina 1. Schemat systemu fosforylacji oksydacyjnej w mitochondriach zwierzęcych. Zaznaczono grupy prostetyczne poszczególnych kompleksów oddechowych biorące udział w transporcie elektronów. cyt - cytochromy, mQ - mitochondrialny koenzym Q, e- - elektrony.

\section{prof. dr hab. Wiesława Jarmuszkiewicz*}

Zakład Bioenergetyki, Instytut Biologii Molekularnej i Biotechnologii, Uniwersytet im Adama Mickiewicza w Poznaniu

https://doi.org/10.18388/pb.2019_289

$\square_{\text {autor korespondujący: wiesiaj@amu.edu.pl }}$

Słowa kluczowe: mitochondria, koenzym $\mathrm{Q}$, łańcuch oddechowy, reaktywne formy tlenu, właściwości antyoksydacyjne i prooksydacyjne

Wykaz skrótów: ATP - adenozyno-5' trifosforan; $\mathrm{FADH}_{2}$ - dinukleotyd flawinoadeninowy; FMN - mononukleotyd flawinowy; HMG-CoA - 3-hydroksy-3-metyloglutarylo-koenzym A; LDL - lipoproteiny niskiej gęstości, $\mathrm{mQ}$ - mitochondrialny koenzym $\mathrm{Q}$; $\mathrm{mRFT}$ mitochondrialne reaktywne formy tlenu; $\mathrm{m} \Delta \Psi$ - mitochondrialny potencjał transbłonowy $\mathrm{NADH}$ - dinukleotyd nikotynoamidoadeninowy; oksydoreduktaza ETF-Q - flawoproteina transportująca elektrony; $\mathrm{O}_{2}{ }^{-}-$anionorodnik ponadtlenkowy; $\mathrm{Q}$ - koenzym $\mathrm{Q}$, chinon; $\mathrm{QH}_{2}$ - zredukowany koenzym $\mathrm{Q}$, chinol; $\mathrm{QH}^{*}$ - semichinon; RFT - reaktywne formy tlenu

Podziękowania: Badania prowadzone przez autorów niniejszej pracy przeglądowej są finansowane przez Narodowe Centrum Nauki w ramach projektu OPUS (2016/21/B/ NZ3/00333). 


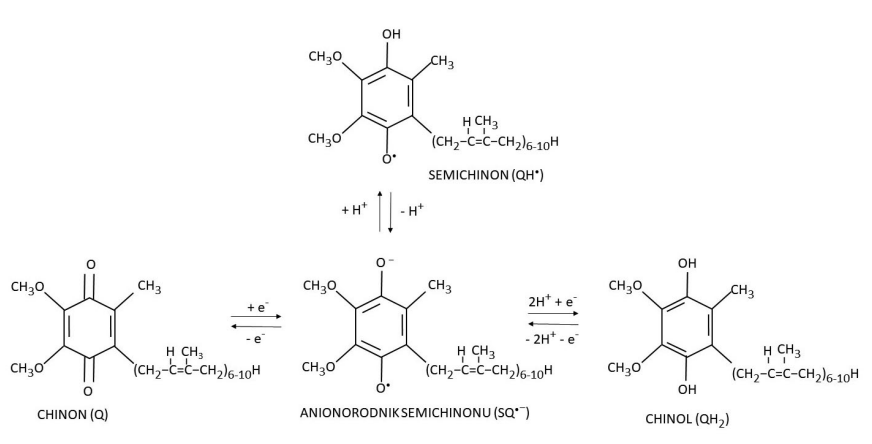

Rycina 2. Stany redoks koenzymu Q.

dza zwrotny przepływ protonów przez syntazę ATP i tym samym produkcję ATP. Dysfunkcja łańcucha oddechowego prowadzi do zmniejszenia produkcji energii i wzrostu produkcji toksycznych mitochondrialnych reaktywnych form tlenu (mRFT). Ponadto uszkodzone mitochondria uwalniają czynniki apoptotyczne, które działają jak sygnały wywołujące śmierć komórki.

\section{MITOCHONDRIALNY KOENZYM Q}

Mitochondrialny $Q$ jest mobilną cząsteczką mitochondrialnego łańcucha transportu elektronów. Aktywna oksydoredukcyjnie benzochinonowa grupa główna cząsteczki $\mathrm{Q}$ jest sprzężona $\mathrm{z}$ bocznym łańcuchem izoprenowym o długości specyficznej dla danego gatunku (od 6 do 10 jednostek). Na przykład, u ludzi występuje mQ z 10 jednostkami izoprenowymi (Q10), u gryzoni głównie Q9, ale także niewielkie ilości Q10, natomiast u drożdży Saccharomyces cerevisiae - Q6 [3]. W mitochondrialnym łańcuchu oddechowym $\mathrm{mQ}$ występuje $\mathrm{w}$ trzech różnych stanach oksydoredukcyjnych: całkowicie utlenionym (chinon, Q), całkowicie zredukowanym (chinol, $\mathrm{QH}_{2}$ ) oraz jako rodnik semichinonowy (semichinon, $\mathrm{QH}^{*}$ ) (Ryc. 2).

Po raz pierwszy $\mathrm{mQ}$ został wyizolowany $\mathrm{z}$ mitochondriów serca wołu przez Crane i wsp. w 1957 roku [4]. Od tej pory liczne badania dowiodły, iż jest on kluczowym elementem mitochondrialnego łańcucha oddechowego bioracym udział $\mathrm{w}$ tworzeniu mitochondrialnego potencjału błonowego $(\mathrm{m} \Delta \Psi)$ oraz w procesie fosforylacji oksydacyjnej. Oprócz podstawowych kompleksów łańcucha oddechowego (kompleks I i II) (Ryc. 1), mQ odbiera elektrony od szeregu innych oksydoreduktaz, które redukują $\mathrm{Q}$ do $\mathrm{QH}_{2}$ (Tab. 1) [5]. W przypadku mitochondriów niektórych grzybów i pierwotniaków oraz w mitochondriach roślin funkcjonują dodatkowe dehydrogenazy $\mathrm{NAD}(\mathrm{P}) \mathrm{H}$ [6]. Zredukowany $\mathrm{mQ}$ (chinol, $\mathrm{QH}_{2}$ ) jest utleniany przez drogę cytochromową (jedyna droga utleniająca $\mathrm{QH}_{2} \mathrm{u}$ zwierząt) oraz dodatkowo przez drogę alternatywną (oksydazę alternatywną) w mitochondriach niektórych grzybów i pierwotniaków oraz w mitochondriach roślin.

W hydrofilowej domenie kompleksu I (oksydoreduktaza NADH:Q) zachodzą reakcje redukcji $\mathrm{mQ}$, generując tym samym siłę napędową dla translokacji czterech protonów. NADH łącząc się z kompleksem I przenosi dwa elektrony do grupy prostetycznej mononukleotydu flawinowego (FMN), tworząc FMNH ${ }_{2}$. Nastepnie elektrony przenoszone są przez centra żelazo-siarkowe i przekazywane na $\mathrm{mQ}$, który przyjmując dwa elektrony ulega redukcji do $\mathrm{QH}_{2}$. Przepływ elektronów przez kompleks indukuje zmiany konformacyjne białka, powodując tym samym translokację czterech jonów wodorowych z macierzy mitochondrialnej do przestrzeni międzybłonowej [7]. Reduktaza bursztynian-Q jest drugim kompleksem mitochondrialnego łańcucha oddechowego, która uczestniczy w cyklu kwasów trikarboksylowych (cyklu kwasu cytrynowego, cyklu Krebsa). Enzym ten, utleniając bursztynian do fumaranu, redukuje $\mathrm{mQ}$, wprowadzając tym samym do mitochondrialnego łańcucha oddechowego dwa elektrony [8]. Źródłem elektronów niezbędnych dla redukcji Q może być także duża rodzina flawoprotein transportujących elektrony, która dostarcza elektrony z różnych dehydrogenaz mitochondrialnych do puli mQ (Tab. 1) [9]. Wśród nich znajduje się oksydoreduktaza ETF-Q (flawoproteina transportująca elektrony, ang. electron transfer flavoprotein) przenosząca elektrony na $\mathrm{mQ} \mathrm{z} \mathrm{FADH}_{2}$, produktu procesu $\beta$-oksydacji kwasów tłuszczowych w macierzy mitochondrialnej [10]. Mitochondrialny Q jest także redukowany przez reakcję utleniania dihydroorotanu do orotanu $\mathrm{z}$ udziałem dehydrogenazy dihydroorotanu [11,12]. Jest to kluczowy enzym cyklu biosyntezy nukleotydów pirymidynowych, który wpływa na produkcję mRFT. Do puli $\mathrm{mQ}$ elektrony dostarczane są także przez dehydrogenazę prolinową czy dehydrogenazą glicerolo-3-fosforanową.

Tabela 1. Miejsca produkcji mRFT przez mitochondria utleniające różne substraty oddechowe.

Miejsca produkcji mRFT

Związane z mQ

Redukujące Q w kompleksie I (IQ)

Flawina/chinon dehydrogenazy glicerolo-3-fosforanu (GF/O)

Dehydrogenaza prolinowa

Utleniające QH2 w kompleksie III (IIIQo)

Flawina kompleksu II (IIF)

Dehydrogenaza dihydroorotanowa

Oksydoreduktaza ETF-Q
Inne

Miejsce flawina/liponian dehydrogenazy 2-oksoglutaranu (OF/L)

Dehydrogenaza pirogronianu

Flawina kompleksu I (IF) 


\section{CYKL mQ}

Cytochrom bc $c_{1}$ (cyt $b c_{1}$ ) czyli kompleks III łańcucha oddechowego katalizuje serię reakcji przeniesienia elektronu ze zredukowanego koenzymu $\mathrm{Q}\left(\mathrm{QH}_{2}\right)$ na cyt $\mathrm{b} c_{1}$. Kolejne reakcje utleniania i redukcji $Q \mathrm{w}$ cyt $b c_{1}$, które prowadzą do przenoszenia protonów przez wewnętrzną błonę mitochondrialną do przestrzeni międzybłonowej nazwano cyklem Q (Ryc. 3).

Transport elektronów zachodzi pomiędzy licznymi miejscami katalitycznymi kompleksów łańcucha oddechowego, które połączone są przez dwa mobilne nośniki elektronów - Q oraz cyt $b c_{1}$. Nośniki te tworzą dwie pule redoks o różnej polarności. Pula $\mathrm{C}$ utworzona przez cyt $\mathrm{b} c_{1}$, zlokalizowana jest $\mathrm{w}$ pobliżu hydrofilowej fazy mitochondrialnej przestrzeni międzybłonowej, natomiast pula Q, formowana przez cząsteczki ubichinonu (Q), znajduje się w sąsiedztwie fazy hydrofobowej wewnętrznej błony mitochondrialnej [13]. Cyt bc jest miejscem łączącym pulę C i Q, które znacząco różnią się między sobą środkowym punktem potencjału redoks. W normalnych warunkach fizjologicznych mitochondriów, transfer elektronów następuje $\mathrm{z} \mathrm{QH}_{2}$ do cyt $c$, a energia pochodząca $z$ tego cyklu wykorzystywana jest do transportu elektronów w poprzek wewnętrznej błony mitochondrialnej. Ze względu na dynamiczne zmiany stanu redoks puli Q i C, siła redukująca puli Q i utleniająca C mogą zależeć również od poziomu utlenienia i redukcji poszczególnych składników. W serii reakcji redukcji i utleniania zachodzących na cyt $b c_{1}$ biorą udział 4 centra metalowe poszczególnych monomerów: hem $b_{\mathrm{H}} \mathrm{i} b_{\mathrm{L}}$ na cyt $\mathrm{b}$ oraz hem $c_{1}$ i centrum Rieskego na cyt $c$ przez które przechodzą elektrony. Energia dostarczona podczas transferu elektronów pomiędzy kompleksami, wykorzystana zostaje w reakcji redukcji chinonu $(\mathrm{Q})$ oraz utleniania chinolu $\left(\mathrm{QH}_{2}\right)$, które zachodzą w dwóch oddalonych od siebie miejscach katalitycznych $\mathrm{Q}_{\mathrm{i}}$ (inaczej $\mathrm{Q}_{\mathrm{N}}$ ) oraz $\mathrm{Q}_{\mathrm{o}}$ (inaczej $\mathrm{Q}_{\mathrm{N}}$ ). Miejsce wiązania i utleniania $\mathrm{QH}_{2}\left(\mathrm{Q}_{\mathrm{o}}\right)$ zlokalizowane jest w stronę przestrzeni międzybłonowej podczas gdy wiązanie i redukcja $Q\left(Q_{i}\right)$ występuje w macierzy mitochondrialnej [14].

Reakcje utleniania dwóch cząsteczek chinolu $\left(\mathrm{QH}_{2}\right)$ rozpoczynają się w miejscu $\mathrm{Q}_{\mathrm{o}}[13,15]$. Pierwszy elektron przechodzi wzdłuż łańcucha o wysokim potencjale przekazywania elektronów (łańcuch c) i oddawany jest na białko Rieskego redukując zawarte w nim żelazo. Dalej elektron trafia na cyt $c_{1}$ redukując żelazo a następnie na cyt $c$ który nie jest związany z kompleksem III. Drugi elektron, który dostarczany jest z powstałego semichinonu w miejscu $\mathrm{Q}_{\mathrm{o}}$, translokowany jest przez łańcuch o niskim potencjale przekazywania elektronów (łańcuch b) zawierający hem $b_{\mathrm{H}} \mathrm{i} b_{\mathrm{L}}$ i dalej do miejsca katalitycznego $\mathrm{Q}_{\mathrm{i}}$. Elektron $\mathrm{w}$ tym miejscu redukuje $\mathrm{Q}$ do $\mathrm{QH}^{*}$. Dopiero redukcja drugiej cząsteczki chinolu dostarcza przez łańcuch b kolejny elektron do całkowitej redukcji $\mathrm{QH}^{*}$ do $\mathrm{QH}_{2}$. Natomiast drugi elektron drugiej redukowanej cząsteczki $\mathrm{QH}_{2}$ przenoszony jest przez łańcuch b redukując drugą cząsteczkę cyt $c$. Tak więc utlenianie dwóch cząsteczek $\mathrm{QH}_{2}$ prowadzi do redukcji dwóch cząsteczek cyt $c$ i jednej cząsteczki Q. Kompleks III jest jednocześnie miejscem translokacji protonów w poprzek wewnętrznej błony mitochondrialnej. Podczas utleniania dwóch cząsteczek $\mathrm{QH}_{2}$ uwalniane zostają cztery

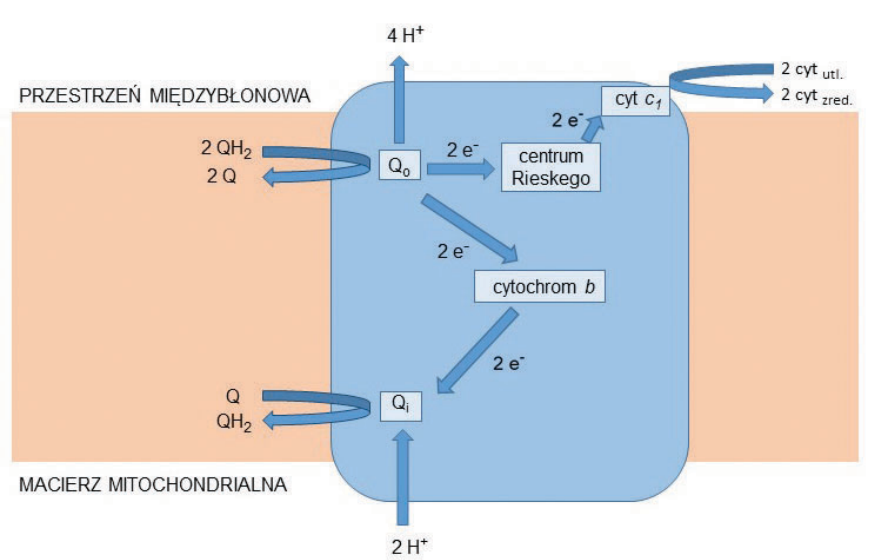

Rycina 3. Cykl mQ. Q - koenzym $\mathrm{Q}$, ubichinon, $\mathrm{QH}_{2}$ - zredukowany ubichinon, ubichinol; $\mathrm{Q}_{\mathrm{o}}$ - miejsce wiążące $\mathrm{QH}_{2}\left(\mathrm{Q}_{\mathrm{P}}\right), \mathrm{O}_{\mathrm{i}}$ - miejsce wiążące $\mathrm{Q}\left(\mathrm{Q}_{\mathrm{N}}\right)$.

protony do przestrzeni międzybłonowej, natomiast przy redukcji Q pobrane zostają z macierzy mitochondrialnej dwa protony [14].

Cyt $b c_{1}$ jest kluczowym enzymem dla szlaku transportu elektronów związanych z wewnętrzną błoną mitochondrialną. Ta niezwykła maszyneria odbiera i przekazuje elektrony pomiędzy różnymi kofaktorami znajdującymi się w różnych stanach redoks. Dzięki temu cyt $b c_{1}$ reguluje przepływ elektronów w łańcuchu oddechowym oraz budowanie $m \Delta \Psi$ w poprzek wewnętrznej błony mitochondrialnej [16].

\section{BIOSYNTEZA Q}

Proces biosyntezy koenzymu Q (Ryc. 4) zachodzi endogennie we wszystkich żywych komórkach i łączy w sobie dwa odrębne szlaki metaboliczne. Chinonowe ugrupowanie dostarczane jest na drodze przemian tyrozyny lub fenyloalaniny do 4-hydroksybenzoesanu, natomiast część poliprenylowa syntetyzowana jest $\mathrm{z}$ acetylo-CoA w cyklu kwasu mewalonowego [17]. Proces ten rozpoczyna się w retikulum endoplazmatycznym a kończy w aparacie Golgiego, skąd dalej $\mathrm{Q}$ przenoszony jest do innych miejsc w komórce [18].

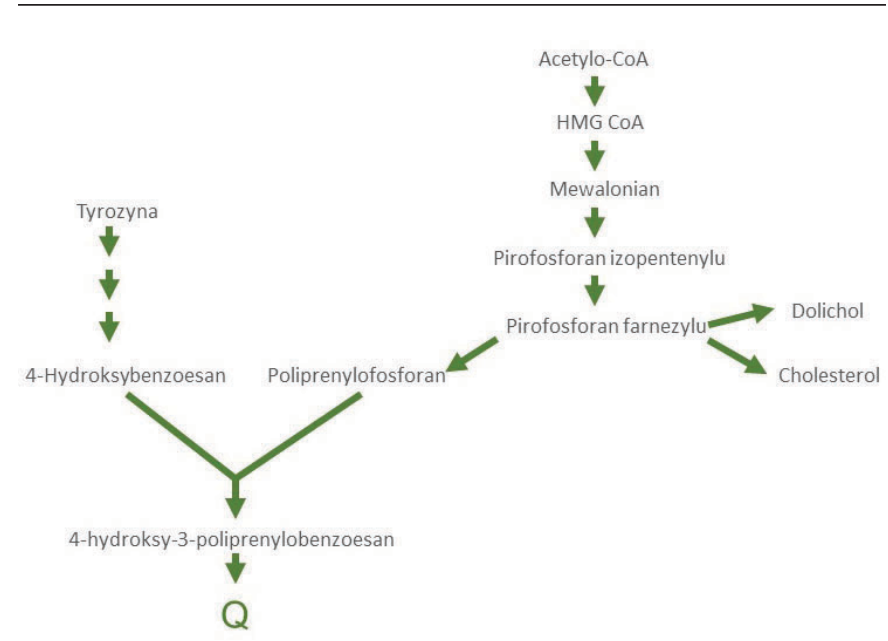

Rycina 4. Schemat biosyntezy Q. HMG CoA - 3-hydroksy-3-metyloglutarylo-koenzym A. 
Cykl kwasu mewalonowego rozpoczyna się od kondensacji trzech cząsteczek acetylo-CoA do 3-hydroksy-3-metyloglutarylo-koenzymu A (HMG-CoA) w obecności enzymów: tiolazy acetoacetylo-CoA oraz syntazy HMG-CoA [18]. Powstały HMG-CoA w obecności reduktazy HMG-CoA, kluczowego enzymu biosyntezy cholesterolu, ulega redukcji do mewalonianu. Jego produkcja może zostać zablokowana przez kompaktynę lub mewinolin, inhibitory obecne w niektórych narkotykach. Kolejnym etapem biosyntezy $\mathrm{Q}$ jest dwuetapowa fosforylacja mewalonianu, w obecności kinazy mewalonianu i kinazy fosfomewalonianu. Produktem jest fosforan mewalonianu, ulegający dekarboksylacji do pirofosforanu izopentenylu (IPP). Syntaza pirofosforanu farnezylu przekształca pirofosforan izopentenylu w pirofosforan farnezylu (FPP) z wytworzeniem produktu ubocznego, pirofosforanu geranylu (GPP). Końcowym etapem jest wydłużanie łańcucha pirofosforanu farnezylu do określonej ilości członów poliprenylofosforanu w obecności transferazy transprenylowej. W zależności od gatunku liczba łańcuchów izoprenowych może wynosić od 6 do 10.

Drugim substratem niezbędnym dla syntezy $Q$ jest 4-hydroksybenzoesan, który powstaje $\mathrm{w}$ wyniku przemian tyrozyny, rzadziej fenyloalaniny, natomiast enzymy biorące udział w tym cyklu nie są do końca zdefiniowane. Proces przemiany tyrozyny $\mathrm{w}$ 4-hydroksybenzoesan występuje głównie u drożdży. W odróżnieniu do ssaków, bakterie i drożdże mogą produkować 4-hydroksybenzen de novo $\mathrm{w}$ cyklu kwasu szikimowego. W końcowym efekcie łańcuch poliprenowy $\mathrm{w}$ obecności transferazy poliprenowej zostaje przeniesiony na 4-hydroksybenzoesan z wytworzeniem 4-hydroksy-3-poliprenylobenzoesanu. W wyniku licznych reakcji pierścień benzoesowy zostaje przekształcony w chinonowy, co prowadzi do ostatecznego uformowania cząsteczki Q.

\section{mQ A PRODUKCJA mRFT}

Jako pierwsi Chance i wsp. wykazali w latach 70-tych ubiegłego wieku, że izolowane mitochondria serca produkują RFT [19]. Obecnie przyjmuje się, że mitochondria są głównym miejscem produkcji RFT (mRFT) w komórkach eukariotycznych [20,21]. Źródłem mRFT jest tzw. przeciek elektronów, którego skutkiem jest jednoelektronowa redukcja tlenu i powstanie anionorodnika ponadtlenkowego, $\left(\mathrm{O}_{2}{ }^{-}\right)$, który jest prekursorem innych RFT. Mitochondrialne RFT z jednej strony mogą prowadzić do uszkodzeń oksydacyjnych, które leżą u podstaw wielu chorób i procesów starzenia, z drugiej strony mogą pełnić rolę cząsteczek sygnałowych wysyłanych z mitochondriów do innych części komórki. Za główne miejsca produkcji mitochondrialnych RFT uważa się nośniki elektronów w łańcuchu oddechowym, a spośród nich przede wszystkim kompleksy białkowe związane z mQ, głównie kompleks I i kompleks III (Ryc. 3). W mitochondriach ssaków scharakteryzowano co najmniej 10 miejsc produkcji anionorodnika ponadtlenkowego $\left(\mathrm{O}_{2}{ }^{-}\right)$czy nadtlenku wodoru $\mathrm{H}_{2} \mathrm{O}_{2} \mathrm{~W}$ łańcuchu oddechowym i w powiązanych z nim enzymach, $w$ tym enzymach z cyklu Krebsa czy $\beta$-oksydacji kwasów tłuszczowych [9].
W kompleksie I przepływ elektronów następuje z NADH do FMN [22]. Elektrony przenoszone są przez siedem centrów Fe-S do miejsca redukcji mQ. Ostatnie centrum Fe-S jest miejscem oddziaływania z semichinonem. Elektrony ze zredukowanego FMN dostarczane są do Q w dwóch jednoelektronowych etapach. Dostarczenie pierwszego elektronu prowadzi do powstania przejściowej formy $Q$, semichino$\mathrm{nu}\left(\mathrm{QH}^{*}\right)$. Transfer drugiego elektronu całkowicie redukuje cząsteczkę Q. Forma przejściowa, $\mathrm{QH}^{*}$, może wchodzić w reakcje z tlenem i prowadzić do powstania anionorodnika ponadtlenkowego $\left(\mathrm{O}_{2}{ }^{-}\right)$.

Innym mechanizmem produkcji $\mathrm{O}_{2}{ }^{-}$związanym z kompleksem I i Q jest odwrotny transport elektronów (ang. reverse electron transport) $[20,21]$. Jest to seria reakcji w łańcuchu oddechowym, która przyczynia się do transferu elektronów wbrew gradientowi potencjału redoks. Elektrony wracają z $\mathrm{QH}_{2}$ i redukują $\mathrm{NAD}^{+}$do NADH w miejscu FMN kompleksu I. Do jednoczesnej redukcji $\mathrm{QH}_{2}$ i produkcji mRFT wymagany jest wysoki $\mathrm{m} \Delta \Psi$ uzyskany na drodze hydrolizy ATP. Zablokowanie miejsca redukcji $\mathrm{QH}_{2}$ kompleksu I prowadzi do zablokowania odwrotnego transportu elektronów i do zmniejszonej produkcji mRFT.

Mechanizm produkcji mRFT przez kompleks III jest dokładnie poznany $[13,23,24]$. Elektrony w tym kompleksie są przenoszone $\mathrm{z} \mathrm{QH}_{2}$ do cyt $c$ przez cykl $\mathrm{Q}$. W normalnych warunkach, przy braku inhibitorów kompleksu III, miejsce $\mathrm{Q}_{\mathrm{o}} \mathrm{w}$ którym powstaje semichinon nie jest stabilne, a produkcja mRFT jest niewielka. Przy odpowiedniej ilości dostarczanego $\mathrm{QH}_{2}$ oraz przy zahamowaniu miejsca $\mathrm{Q}_{\mathrm{i}}$ przez cyjanek, kompleks III produkuje znaczne ilości mRFT w reakcji tlenu z semichinonem. Mitochondrialny $\Delta \Psi$ jest kolejnym czynnikiem wpływającym na produkcję mRFT w miejscu $Q_{0}$ kompleksu $b c_{1}$. Wysoki potencjał transbłonowy obniża transfer elektronów $\mathrm{z}$ hemu $b_{\mathrm{L}}$ do hemu $b_{\mathrm{H}}$ prowadząc do bardziej zredukowanego hemu $b_{\mathrm{L}}$ a tym samym zwiększając produkcję mRFT.

Mechanizmem odpowiedzialnym za wzrost produkcji mRFT jest również stan redoks puli mQ. Stopień redukcji $\mathrm{mQ}$, który wpływa na poziom redukcji $\mathrm{mRFT}$, zależy od aktywności wszystkich dróg redukujących mQ (tzn. dehydrogenaz dostarczających elektrony do puli $\mathrm{mQ}$ ) oraz od aktywności dróg utleniających $\mathrm{mQ}$ (drogi cytochromowej i obecnej w roślinnym typie łańcucha oddechowego oksydazy alternatywnej) [25]. Mitochondria funkcjonują pomiędzy stanem fosforylującym (stanem 3), syntetyzującym ATP, któremu towarzyszy obniżony poziom redukcji $\mathrm{mQ}$, obniżony $\mathrm{m} \Delta \Psi$, zmniejszona produkcja $\mathrm{mRFT}$, i stanem nie-fosforylującym (stanem 4), któremu towarzyszy podwyższony poziom redukcji $\mathrm{mQ}$, podwyższony $\mathrm{m} \Delta \Psi$, zwiększona produkcja mRFT. Niektóre fizjologiczne czynniki, np. aktywność białek rozprzęgających (UCPs, ang. uncoupling proteins), mogą obniżać poziom redukcji $\mathrm{mQ}$, prowadząc do zmniejszenia produkcji mRFT [26]. Kinetyczny opis zależności produkcji $\mathrm{mRFT}$ od $\mathrm{m} \Delta \Psi$ dla niefosforylujących mitochondriów serca szczura pokazuje, że wyraźnie zwiększona produkcja mRFT jest obserwowana po przekroczeniu wartości progowej, $\mathrm{w}$ okolicach $\mathrm{m} \Delta \Psi$ fosforylujących mitochondriów [27]. Badania kinetyczne prowadzone na mito- 
chondriach izolowanych z Acanthamoeba castellanii wskazują na bezpośrednią zależność tworzenia mRFT od poziomu redukcji puli $\mathrm{mQ}$ dla szlaków utleniających $\mathrm{QH}_{2}$ (drogi cytochromowej, tj. kompleksu III i IV oraz oksydazy alternatywnej), obecnych w łańcuchu oddechowym mitochondriów ameby [25]. Wyższy poziom redukcji $\mathrm{mQ}$ prowadzi do większego tworzenia mRFT. W przypadku drogi cytochromowej wytwarzanie mRFT zależy nieliniowo od poziomu redukcji $\mathrm{mQ}$, przy czym silniejszą zależność obserwuje się przy wartościach wyższych niż poziom redukcji mQ stanu fosforylującego (stanu 3) ( 35\%). Oksydaza alternatywna staje się aktywniejsza przy wyższych poziomach redukcji puli $\mathrm{mQ}$ (powyżej 40\%), gdy wzrasta wytwarzanie mRFT przez drogę cytochromową. Zaproponowano, że poziom redukcji puli $\mathrm{mQ}$ (czyli endogenny stan redoks $\mathrm{mQ}$ ) może być użytecznym endogennym markerem, który umożliwia ocenę całkowitej produkcji mRFT w mitochondriach [25]. Należy pamiętać, że produkcja mRFT jest bezpośrednią funkcją poziomu redukcji puli $\mathrm{mQ}$ a nie wielkości $m \Delta \Psi$. Nie zawsze wysoki $\mathrm{m} \Delta \Psi$ oznacza dużą produkcję mRFT. Na przykład w warunkach zahamowania kompleksu III (antymycyną A) czy kompleksu IV (cyjankiem) obniża się $\mathrm{m} \Delta \Psi$, natomiast stopień redukcji $\mathrm{mQ}$ i produkcja $\mathrm{mRFT}$ rosną.

A zatem mQ jest cząsteczką bezpośrednio biorącą udział $\mathrm{w}$ produkcji mRFT $\mathrm{w}$ wyniku tworzenia rodnika ponadtlenkowego $\left(\mathrm{O}_{2}{ }^{-}\right)$z rodnika semichinonowego. Mitochondrialne RFT powstają jako produkt uboczny metabolizmu tlenowego lub w warunkach stresu oksydacyjnego. Wzmożona produkcja mRFT może prowadzić do szeregu uszkodzeń oksydacyjnych. Co ciekawe, z drugiej strony zredukowana forma $m Q$, podobnie jak Q obecnego w innych przedziałach błonowych komórki, pełni rolę niebiałkowego przeciwutleniacza.

\section{ANTYOKSYDACYJNE DZIAŁANIE Q}

Koenzym Q jest jedynym rozpuszczalnym w tłuszczach przeciwutleniaczem syntetyzowanym endogennie. Za właściwości antyoksydacyjne w głównej mierze odpowiadają zredukowane formy $\mathrm{Q}$, chinol $\left(\mathrm{QH}_{2}\right)$ oraz semichinon $\left(\mathrm{QH}^{*}\right)$, natomiast forma utleniona ze względu na brak atomu wodoru nie może pełnić roli przeciwutleniacza [28]. Mechanizm antyoksydacyjnego działania $\mathrm{QH}_{2}$ polega na oddawaniu jednego atomu wodoru i tworzeniu cząsteczki $\mathrm{QH}^{\bullet}$, która dalej może reagować z jeszcze jednym $\mathrm{QH}{ }^{\bullet}$ lub z tlenem cząsteczkowym, prowadzac to powstania Q. Ubichinol wiążąc wolne rodniki hamuje procesy peroksydacji lipidów oraz zapobiega oksydacyjnym modyfikacjom DNA i białek [29].

Ubichinol hamuje peroksydację lipidów błony komórkowej, a także lipidów lipoprotein obecnych w procesie krążenia. Liczne badania nad lipoproteinami niskiej gęstości (LDL) dowodzą, że $\mathrm{QH}_{2}$ skutecznie redukuje rodnik a-tokoferoksylowy (a-TO') będący prooksydantem, do a-tokoferolu (witamina E) [30]. Witamina E jest cząsteczką hydrofobową, która w reakcji z wolnymi rodnikami jak na przykład $\mathrm{QH}^{\bullet}$ wytwarza a-TO. Obecny w błonach komórkowych $\mathrm{QH}_{2}$ wchodzi w interakcje z powstałym rodnikiem a-TO• i odbudowuje cząsteczkę witaminy E do postaci zredukowanej. W wyniku braku lub obniżonego stężenia Q w błonach komórkowych regeneracja witaminy E byłaby po- wolnym procesem. Liczne badania dowodzą, że obecność $\mathrm{QH}_{2}$ w LDL utrzymuje peroksydację lipidów na niskim poziomie [31].

W mitochondriach $\mathrm{QH}_{2}$ zmniejsza peroksydację lipidów bezpośrednio, działając jako przeciwutleniacz zapobiegający samej reakcji peroksydacji i pośrednio poprzez odnawianie puli witaminy E [29]. Działanie $\mathrm{QH}_{2}$ jako antyutleniacza wymaga deprotonacji (i oddania elektronów). Powstały w ten sposób w czasie zapobiegania uszkodzeniom oksydacyjnym utleniony $Q$ jest następnie redukowany z powrotem do $\mathrm{QH}_{2}$ przez mitochondrialny łańcuch oddechowy. Obok zapobiegania peroksydacji lipidów, działanie antyoksydacyjne $\mathrm{QH}^{\bullet}$ polega na wchodzeniu $\mathrm{w}$ reakcję $\mathrm{z}$ innymi reaktywnymi formami tlenu. Zatem, mQ będąc cząsteczką o właściwościach przeciwutleniających i prooksydacyjnych, przyczynia się zarówno do uszkodzeń oksydacyjnych mitochondriów, jak i do ich obrony antyoksydacyjnej.

\section{Q I CHOROBY}

Rośnie zainteresowanie zastosowaniem koenzymu Q i jego związków pokrewnych w terapiach różnych chorób, w których dochodzi do oksydacyjnych uszkodzeń mitochondriów. Istotna jest również ilość $\mathrm{mQ} w$ mitochondriach. $\mathrm{U}$ ssaków, znaczne obniżenie poziomu $\mathrm{mQ}$ może prowadzić do stopniowego obniżania aktywności mitochondriów, stopniowego rozwoju zmian chorobowych i skrócenia życia [32]. Organy o dużym zapotrzebowaniu energetycznym (serce, mózg czy wątroba) posiadają największą ilość mQ.

Tkanki, takie jak serce i mięśnie, potrzebują znacznych ilości $\mathrm{mQ}$ ze względu na ich wysokie zapotrzebowanie na energię [32]. To przecież mitochondria $\mathrm{w}$ procesie fosforylacji oksydacyjnej (w którym istotną funkcję odgrywa $\mathrm{mQ}$ jako składnik łańcucha oddechowego) dostarczają największej ilości ATP komórce. Badania wykazały, że zmiany w ilości Q związane z wiekiem są najbardziej widoczne w mitochondriach i że spadek zawartości mQ może być specyficzny dla pewnych tkanek. Ponadto, wiek i choroby również wpływają na zwiększoną ilość utlenionego Q w porównaniu z formą zredukowaną, co może prowadzić do obniżonego całkowitego poziomu koenzymu w mitochondriach i komórkach.

W ostatnich latach znacząco wzrosło zainteresowanie suplementami diety, które mogą istotnie wpływać na poprawę stanu zdrowia, zwłaszcza w chorobach neurodegeneracyjnych. Jednym z popularnych suplementów stał się Q. Pojawia się coraz więcej dowodów na to, że zaburzenia związane z niedoborem Q odgrywają istotną rolę w rozwoju chorób neurodegeneracyjnych, takich jak choroba Parkinsona czy choroba Alzheimera [33]. Liczne badania wykazały, że u pacjentów z chorobą Parkinsona aktywność kompleksu I jest zmniejszona $\mathrm{w}$ istocie czarnej śródmózgowia, natomiast aktywność kompleksów II, III, IV była porównywalna z kontrolami [34]. Obiecujące badania wstępne na ludziach sugerują, że suplementacja Q może zmniejszyć, ale nie wyleczyć, demencję u osób cierpiących na Alzheimera. Potrzebne są dodatkowe dobrze zaprojektowane badania, aby potwierdzić pozytywne działanie Q w zapobieganiu i leczeniu chorób neurodegeneracyjnych [35]. 
Modyfikacje w składzie lipidów podczas starzenia mają znaczący wpływ na fizykochemiczną strukturę błon oraz działanie enzymów i zachodzących w błonach procesów metabolicznych [36]. Lipidy szlaku mewalonianowego wykazują charakterystyczne zachowanie podczas procesów starzenia. Zawartość Q jest znacznie zwiększona w ciągu pierwszych 20 lat życia człowieka, po czym następuje spadek w różnym stopniu i w niektórych narządach w wieku 80 lat może być niższy niż w chwili urodzenia. Natomiast zarówno dolichol jak i dolichyl-P wzrastają w ciągu całego życia człowieka w dużym stopniu. Co ciekawe, mitochondria izolowane $\mathrm{z}$ tkanek starszych myszy nie wykazują zmian w ilości Q z wyjątkiem mięśni szkieletowych [37].

Przeprowadzono liczne badania mające na celu określenie zależności pomiędzy $Q$ a stanem zapalnym u zwierząt i w modelach komórkowych. Mimo iż w wielu różnych materiałach badawczych pokazano korzystny wpływ koenzymu Q10 na biomarkery zapalne, wyniki badań otrzymanych na pacjentach $\mathrm{z}$ chorobami sercowo-naczyniowymi są sprzeczne. Badania przeprowadzone przez Zhao i wsp. [38] wykazały, że suplementacja $Q$ w dawce $30 \mathrm{mg} /$ dobę przez 6 miesięcy znacząco zmniejszała poziom wysokoczułego białka C-reaktywnego (hs-CRP, ang. high sensitive C-reactive protein), tzw. białka ostrej fazy, w surowicy u pacjentów $\mathrm{z}$ chorobami sercowo-naczyniowymi. Natomiast Pourmoghaddas i wsp. [39] wykazali, że suplementacja Q10 w dawce $200 \mathrm{mg}$ / dobę przez 4 miesiące nie miała istotnego wpływu na poziom hs-CRP w surowicy pacjentów z chorobami sercowo-naczyniowymi.

Niedobór mQ występuje, gdy poziom puli Q w mitochondriach zmniejsza się poniżej $60-70 \% \mathrm{w}$ mięśniach szkieletowych i/lub fibroblastach osób cierpiących na zaburzenia nerwowo-mięśniowe, takie jak ataksja lub zespół nerczycowy oporny na steroidy [16]. Są to rzadkie zaburzenia należące do rodziny chorób mitochondrialnych [40]. Komórki tych pacjentów wykazują dysfunkcyjne mitochondria ze zmniejszoną aktywnością głównie kompleksów I, II oraz III [41]. Patogeneza niedoboru Q wiąże się rozwojem chorób wynikających z działania nadmiernie produkowanych mRFT, co prowadzi do nieprawidłowej pracy łańcucha oddechowego, a w konsekwencji obniża sprawność komórek, tkanek i całego organizmu [42].

Liczne badania nad funkcją Q wskazują na to, jak ważna jest ta cząsteczka dla życia żywych organizmów. Wielu pacjentów reaguje na doustną suplementację Q10, niemniej jednak terapie te są nadal problematyczne ze względu na niską biodostępność związku. Trwają intensywne badania nad nowymi terapiami farmakologicznymi.

\section{PODSUMOWANIE}

Mitochondrialny Q niejedno ma oblicze. Jest podstawowym nośnikiem elektronów w mitochondrialnym łańcuchu transportu elektronów. Z drugiej strony, $\mathrm{mQ}$ uczestniczy w produkcji mRFT przez kompleksy łańcucha oddechowego oraz enzymy będące donorami elektronów w tym szlaku metabolicznym. Mitochondrialne RFT, powstające z udziałem $\mathrm{mQ}$, mogą prowadzić do uszkodzeń oksydacyjnych makrocząsteczek ważnych dla funkcjonowania komórki. W komórce $Q$, który jest obecny we wszystkich błonach komórkowych, w tym mitochondrialnych, we krwi oraz $\mathrm{w}$ lipoproteinach, działa również jako przeciwutleniacz. Mitochondria zawierają najwyższe stężenie $\mathrm{Q}$ i odgrywają znaczącą rolę w produkcji ATP. Zatem tkanki, takie jak serce i mięśnie, potrzebują znacznych ilości $\mathrm{mQ}$ ze względu na ich duże zapotrzebowanie na energię. Ponadto, związane z wiekiem zmiany ilości $Q$ są najbardziej widoczne w mitochondriach niektórych tkanek. Wraz z wiekiem i w niektórych chorobach zwiększa się ilość utlenionego $\mathrm{Q}$ w porównaniu $\mathrm{z}$ formą zredukowaną $\left(\mathrm{QH}_{2}\right)$, co może prowadzić do obniżonego poziomu całkowitej ilości koenzymu. Q jest zatem ważną niebiałkową cząsteczką, która w mitochondriach (i w całej komórce) pełni różne funkcje, od udziału w produkcji energii (jako element łańcucha oddechowego), zapobieganiu uszkodzeniom oksydacyjnym (jako przeciwutleniacz), po udział w produkcji mRFT (jako główne miejsce ich produkcji, czyli jako czynnik prooksydacyjny).

\section{PIŚMIENNICTWO}

1. Friedman JR, Nunnari J (2014) Mitochondrial form and function. Nature 505: 335-343

2. Wojtczak L, Zabłocki K (2008) Mitochondria w życiu, chorobie i śmierci komórki. Postepy Biochem 5: 129-141

3. Bentinger M, Tekle M, Dallner G (2010) Coenzyme Q - biosynthesis and functions. Biochem Biophys Res Commun 396: 74-79

4. Crane FL, Hatefi Y, Lister RL, Widmer C (1957) Isolation of a quinone from beef heart mitochondria. Biochim Biophys Acta 25: 220-221

5. Murphy MP (2009) How mitochondria produce reactive oxygen species. Biochem J 417: 1-13

6. Szal B, Rychter AM (2016) Oksydaza alternatywna - niedokończona opowieść. Postepy Biochem 62: 138-148

7. Sazanov LA (2015) A giant molecular proton pump: structure and mechanism of respiratory complex I. Nat Rev Mol Cell Biol 16: 375-388

8. Anderson RF, Shinde SS, Hille R, Rothery RA, Weiner JH, Rajagukguk S, Maklashina E, Cecchini G (2014) Electron-transfer pathways in the heme and quinone-binding domain of complex II (succinate dehydrogenase). Biochemistry 53: 1637-1646

9. Quinlan CL, Perevoshchikova IV, Hey-Mogensen M, Orr AL, Brand MD (2013) Sites of reactive oxygen species generation by mitochondria oxidizing different substrates. Redox Biol 1: 304-312

10. Watmough NJ, Frerman FE (2010) The electron transfer flavoprotein: ubiquinone oxidoreductases. Biochim Biophys Acta 1797: 1910-1916

11. Hoffman HH, Kunz A, Simon VA, Palese P, Shaw ML (2011) Broad-spectrum antiviral that interferes with de novo pyrimidine biosynthesis. Proc Natl Acad Sci USA 108: 5777-5782

12. Hey-Mogensen M, Goncalves RL, Orr AL, Brand MD (2014) Production of superoxide/ $\mathrm{H} 2 \mathrm{O} 2$ by dihydroorotate dehydrogenase in rat skeletal muscle mitochondria. Free Radic Biol Med 72: 149-155

13. Sarewicz M, Osyczka A (2015) Electronic connection between the quinone and cytochrome $\mathrm{c}$ redox pools and its role in regulation of mitochondrial electron transport and redox signaling. Physiol Rev 95: 219-243

14. Crofts AR, Holland JT, Victoria D, Kolling DR, Dikanov SA, Gilbreth R, Lhee S, Kuras R, Kuras MG (2008) The Q-cycle reviewed: How well does a monomeric mechanism of the bc(1) complex account for the function of a dimeric complex? Biochim Biophys Acta 1777: 1001-1019

15. Cramer WA, Hasan SS, Yamashita E (2011) The Q cycle of cytochrome bc complexes: a structure perspective. Biochim Biophys Acta 1807: $788-802$

16. Alcázar-Fabra M, Navas P, Brea-Calvo G (2016) Coenzyme Q biosynthesis and its role in the respiratory chain structure. Biochim Biophys Acta 1857: 1073-1078 
17. Ernster L, Dallner D (1995) Biochemical, physiological and medical aspects of ubiquinone function. Biochim Biophys Acta 1271: 195-204

18. Turunen M, Olsson J, Dallner G (2004) Metabolism and function of coenzyme Q. Biochim Biophys Acta 1660: 171-199

19. Loschen G, Flohe L, Chance B (1971) Respiratory chain linked $\mathrm{H}_{2} \mathrm{O}_{2}$ production in pigeon heart mitochondria. FEBS Lett 18: 261-264

20. Murphy MP (2009) How mitochondria produce reactive oxygen species. Biochem J 417: 1-13

21. Czarna M, Jarmuszkiewicz W (2006) Rola mitochondriów w wytwarzaniu i usuwaniu reaktywnych form tlenu; związek z przesyłaniem sygnałów i programowaną śmiercią komórki. Postepy Biochem 52: 145-156

22. Wang Y, Hekimi S (2016) Understanding ubiquinone. Trends Cell Biol 26: 367-378

23. Bleier L, Dröse S (2013) Superoxide generation by complex III: from mechanistic rationales to functional consequences. Biochim Biophys Acta 1827: 1320-1331

24. Dröse S, Brandt U (2008) The mechanism of mitochondrial superoxide production by the cytochrome bc1 complex. J Biol Chem 283: 2164921654

25. Dominiak K, Koziel A, Jarmuszkiewicz W (2018) The interplay between mitochondrial reactive oxygen species formation and the coenzyme Q reduction level. Redox Biol 18: 256-265

26. Woyda-Ploszczyca A, Jarmuszkiewicz W (2017) The conserved regulation of mitochondrial uncoupling proteins: From unicellular eukaryotes to mammals. Biochim Biophys Acta 185: 21-33

27. Korshunov SS, Skulachev VP, Starkov AA (1997) High protonic potential actuates a mechanism of production of reactive oxygen species in mitochondria. FEBS Lett 416: 15-18

28. Kapoor P, Kapoor AK (2013) Coenzyme Q10 - a novel molecule. JIACM 2013; 14: 37-45

29. Cobanoglu1 U, Demir H, Çebi A, Sayır F, Alp HH, Akan Z, Gür T, Bakan E (2011) Lipid peroxidation, DNA damage and coenzyme Q10 in lung cancer patients - markers for risk assessment? Asian Pacific J Cancer Prev, 12, 1-4 -56

30. Lass A, Sohal RS (1998) Electron transport-linked ubiquinone-dependent recycling of alpha-tocopherol inhibits autooxidation of mitochondrial membranes. Arch Biochem Biophys 352: 229-236
31. Casagrandea D, Waibb PH, Júniora AAJ (2018) Mechanisms of action and effects of the administration of coenzyme Q10 on metabolic syndrome. Journal of Nutrition \& Intermediary Metabolism 13: 26-32

32. Wang Y, Oxer D, Hekimi S (2015) Mitochondrial function and lifespan of mice with controlled ubiquinone biosynthesis. Nat Commun 6: 6393

33. Ogawa O, Zhu X, Perry G, Smith MA (2002) Mitochondrial abnormalities and oxidative imbalance in neurodegenerative disease. Sci Aging Knowledge Environ 2002: pe16

34. Parker WD, Parks JK, Swerdlow RH (2008) Complex I deficiency in Parkinson's disease frontal cortex. Brain Res 1189: 215-218

35. Nicolson GL (2014) Mitochondrial dysfunction and chronic disease: treatment with natural supplements. Integr Med (Encinitas) 13: 35-43

36. Kalén A, Appelkvist EL, Dallner G (1989) Age-related changes in the lipid compositions of rat and human tissues. Lipids 24: 579-584

37. Lass A, Kwong L, Sohal RS (1999) Mitochondrial coenzyme Q content and aging. Biofactors 9: 199-205

38. Zhao Q, Kebbati AH, Zhang Y, Tang Y, Okello E, Huang C (2015) Effect of coenzyme Q10 on the incidence of atrial fibrillation in patients with heart failure. J Investig Med. 63: 735-739

39. Pourmoghaddas M, Rabbani M, Shahabi J, Garakyaraghi M, Khanjani R, Hedayat P (2014) Combination of atorvastatin/coenzyme Q10 as adjunctive treatment in congestive heart failure: A double-blind randomized placebo-controlled clinical trial. ARYA Atheroscler 10: 1-5

40. González-Mariscal I, García-Testón E, Padilla S, Martín-Montalvo A, Pomares Viciana T, Vazquez-Fonseca L, Gandolfo Domínguez P, Santos-Ocaña C (2014) The regulation of coenzyme q biosynthesis in eukaryotic cells: all that yeast can tell us. Mol Syndromol 5: 107-118

41. Doimo M, Desbats MA, Cerqua C, Cassina M, Trevisson E, Salviati L (2014) Genetics of coenzyme q10 deficiency. Mol Syndromol 5: 156-162

42. Noh YH, Kim KY, Shim MS, Choi SH, Choi S, Ellisman MH, Weinreb RN, Perkins GA, Ju1 WK (2013) Inhibition of oxidative stress by coenzyme Q10 increases mitochondrial mass and improves bioenergetic function in optic nerve head astrocytes. Cell Death Dis. 4: e820

\title{
Different faces of the mitochondrial coenzyme $Q$
}

\section{Karolina Dominiak, Wieslawa Jarmuszkiewicz ${ }^{\bigotimes}$}

Department of Bioenergetics, Institute of Molecular Biology and Biotechnology, Adam Mickiewicz University, 6 Uniwersytetu Poznańskiego Str., 61-614 Poznań, Poland

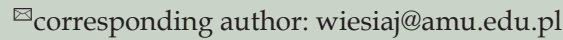

Key words: mitochondria, coenzyme Q, respiratory chain, oxidative phosphorylation, reactive oxygen species, antioxidative and prooxidative properties

\begin{abstract}
Coenzyme $Q$ is a fat-soluble molecule present in all cell membranes, including the inner mitochondrial membrane. Mitochondrial $Q$ ( $\mathrm{mQ}$ ) is a key electron carrier in the respiratory chain and an important antioxidant. On the other hand, mQ participates in the production by respiratory chain of mitochondrial reactive oxygen species (mROS) that are formed as a byproduct of oxygen metabolism or under oxidative stress conditions. Increased mROS production can lead to a series of oxidative damage that underlies cell aging or a number of diseases. In addition, mROS act as signaling molecules. Respiratory chain electron carriers, primarily mQ-related protein complexes, are considered the main mROS production sites. With age, the level of $Q$, and in particular its reduced form, decreases in the body. Disorders associated with coenzyme $Q$ deficiency are mainly associated with excessive mROS production and a decrease in ATP production, which may result in mitochondrial, cardiovascular or neurodegenerative diseases.
\end{abstract}

